\title{
Public Transport Study in Dohuk City
}

\author{
S. A. Sarhan \\ Assistant Lecturer \\ College of Engineering \\ Dohuk University
}

\begin{abstract}
In this study, the public transport in Dohuk City is investigated. Questionnaire forms were prepared and used to collect socio-economic data from transit riders, their origins and destinations, trip purpose, and their mode of transport. Low standard of living residents in this city are captive to use public transport, with out scheduling of transit, especially males of (18-25) years old. The people who are using transit their home are far a way from the road for a distance more than (200)m. Out of the data analyzed some conclusions and recommendations are presented in order to be considered by experts and specialists in this city to take them under option in the future to develop the transit routes and modes.
\end{abstract}

Key Word: Public Transport Dohuk

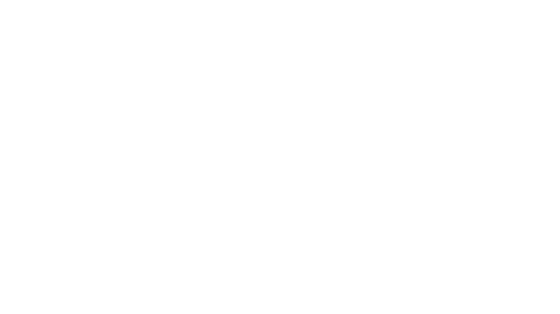

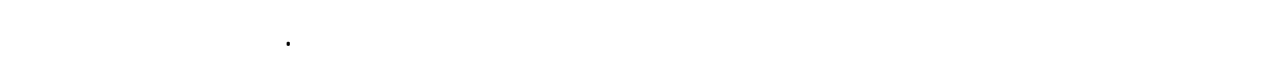

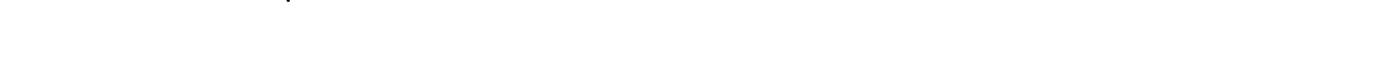

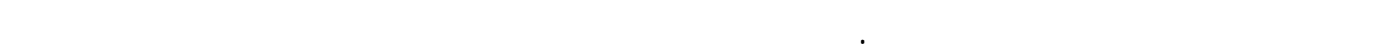

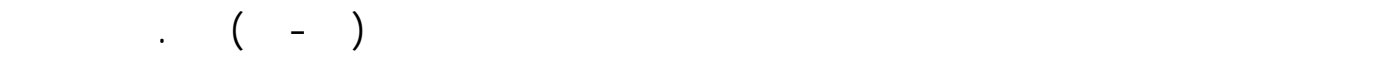

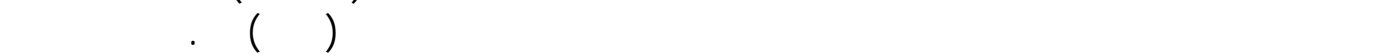

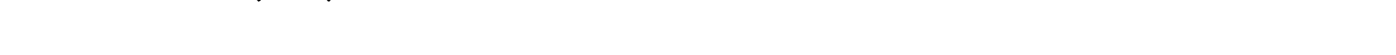
والمختصني في المدينة لغرض تمسين أنمطا ومسارات الثل في المسنقل.

كلمة الدلالة: الثل العلم دهوك 


\section{Introduction and Purpose}

Public transit in any city is very essential tool for daily movement of different public sectors of the society. The new and large cities may have efficient transit system to link the function units in different parts of the city, whether residential, administration, industrial, trading, educational and recreational. The need for public transport is highly increased due to the high expansion and complication of the different life needs to think for suitable alternatives to face this complication, local officials and business-men have became aware that poor transit service may be detrimental to the orderly development of a community. Other factors like rider's sex, income groups, car ownership, family size, and percent riders using transit are also introduced in order to find their effect on the travel demand for public transport in Dohuk city. Directional demand was covered to know which direction of flow is carrying the greater number of riders.

The purpose of this study is to evaluate the present condition of the public transport in the center of Dohuk city representing the trading markets, shops, hotels, offices and the out bounds of the city representing the sectors of Serhaldan, Diyary, Jamiea and Reza. The low standard of living for a relatively important sector of the city which are captive riders for public transport especially the bus is another cause to conduct this study. In general scope of the study includes the following:

1- collection and interpretation of facts about the present public transit system in Dohuk city.

2- Identification of present deficiencies and to recommend a planning program to remedy the deficiency.

3- Determination of what modes, if any, of mass transit are convenient for the movement of people from and to the city.

\section{Review of Literature}

The transit planning in the north-eastern of Mosul city was studied by Abdul-Basit Mahmood. The study area covered an estimated population of 85303 inhabitants and an area of 13.75 square kilometers. He collected three types of data concerning, transit users, bus operations, and existing transit system. The study found that there were (7) publicly owned buses serving 15,870 riders during a typical weekday. These buses made 105 roundtrips daily and covering 60 percent of the total study area, in addition to (20) privately owned bused and minibuses serving 15,768 riders. ${ }^{[1]}$

According to Levinson, the traditional market for fixed-schedule bus system developed residential neighborhoods surrounding the Central Business District CBD. Travel within CBD was pedestrian and shuttle bus oriented, while suburban to-CBD work trips were more adequately handled by either rail or express bus operation. Trips from older center city ring areas, then, particularly those which were CBD-oriented, appear to be most adequately served by conventional fixed-route, fixed-schedule bus system. ${ }^{[3]}$

Hill, proposed densities of about 6500 persons per square mile for fixedroute, fixed-schedule operation ${ }^{[4]}$. Roos, had stated that traditional fixed-route, 
fixed-schedule bus systems required densities of only 6000 people per square mile or in another way required at least 80 demands per square mile per hour for economical operation. ${ }^{[5]}$

St. Louis study, concluded that although delay time due to traffic conditions and signal controls accounted for about 12 percent of total bus transit trip time, delays due to passenger pickup and discharge amounted to almost 18 percent of the total trip time. ${ }^{[6]}$

Berry, suggested that optimum location of bus stops might be effective in reducing that portion of delay time due to passenger boarding and alighting and might subsequently increase bus transit operating speeds some what. ${ }^{[7]}$

Deen and pratl (1992), indicate three primary factors that should be carefully identified and studied before embarking on a transit project. ${ }^{[8]}$

1- Financial and institutional factors, that indicate the constraints within which the system is to be planned, financed, designed, built and made operational.

2- Attitudinal factors that exist in the community independent of the plan and/ or the planning process for the transit system.

3- Physical and analytical factors that involve the physical layout of the system and the readership it is supposed to serve. Interaction with other modes of transportation must also be critically examined.

The Transit Capacity and Quality of Service Manual(TRB,1999), addresses four service measures related to transit facilities; service frequency, hours of service, passenger loads, and reliability ${ }^{[9]}$. Two other performance measures relating to transit systems- service coverage, and transit or automobile travel time, and their application to corridor and area wide analyses are included.

\section{Problem Definition}

Urban problems such as energy shortages, congestion, and increasing highway costs are prompting communities to reassess the need for public transportation. A solution can be achieved if citizens are encouraged to rely less on the automobile and more on public modes for intercommunity travel. However, achieving user shifts in mode preferences is not an easy task because of the automobile's popularity, and to a certain extent it's availability.

The new Urban transit modes which combine the best characteristics of both modes (Private automobiles, and public transit) are the intended objective of the community. The characteristics of private automobile, public transit, and new transit modes are shown in Fig $(1)^{[1]}$.

The study view point toward public transportation in Dohuk City do not encompasses alternatives such as rail rapid transit, and rail fixed-route, fixed schedule systems, car and bus pooling, taxi cabs, and demand-responsive systems (e.g. dial-a-bus, and shopper minibuses).

The goal setting process should consider all feasible system alternatives in a particular urban community, because of the wide variation of factors that influence public transportation from one city to another, goal determination should be specific for each community as shown in $\operatorname{Fig}(2)^{[2]}$. The goal of the study is aimed to improve public transport system in the interior corridors of Dohuk City. 


\section{Study Area}

The area selected for this study includes the Dohuk City center represented by the trading markets offices, shop, hotels and other residential sectors. The out bounds of the city represented by the sectors surrounded by Sarsong city arterial street from the east, called Serhildan, and Diyary bus lines, the west bounds of city included in this located at the western-north of the city called, Jamiea, and Reza bus lines at the south direction from the city center of Dohuk. The studied area includes mostly residential sectors serviced by minibuses of (12) persons in seating capacity. Fig(3) shows the master plan of Dohuk city representing the area of study with the different routes of bus services from out bounds to the city center, Malta bus route is not included in this study.

Data Requirement for Estimating Transit Demand: The estimate of transit demands is based on the knowledge of existing transit demands and the existing relationship between transit and land use activities. These relationships are then applied to future land use activities thus translating future land use into future transit requirements.

The above relationships are based and data collected by means of sample survey of the population. The transit demand surveys are designed to provide a detailed description of the travel demand characteristics. The survey is usually conducted by interviewing the transit users, and collecting the data by asking them to fill the questionnaire form which is designed for this purpose.

Development of the Questionnaire Form:

The an-board transit questionnaire survey was designed to serve dual purposes:

1- To provide information needed in long-range planning.

2- To provide information needed in operational planning.

A (14) questions on the survey cards were prepared as shown in Fig.(4). A brief description of the questionnaire form is given below:

Question 1: The complaints of transit riders. This enabled the study to know the deficiency in the existing transit system.

Question 2: The convenient times of using the bus daily. This was needed in order to classify travel by time periods.

Question 3: and 5: the address of origin and destination of trip makers.

Question 4 and 6: These questions were asked to identify trip purposes. Trip purposes considered in this study are, Home-based, Home-based to work, school, shopping, and others. This information is necessary for taking into account such detail for future transit planning.

Question 7: Riders profession, sex, and age. This question was asked in order to identity the characteristics of transit user.

Question 8: The walking distance between bus stop and place of residence. This was needed in order to measure the effectiveness of transit route which was used in operation planning. Question 9, 10 and 11: Does the rider own a car? Why do you prefer to choose the bus? Number of times the rider use the bus. This series of questions are asked in order to determine whether the passenger was a "choice" or "captive" transit rider. Question 12, 13, 14: Number of family members. Number of family member using the bus. The family income per month (optional). These 
questions were designed to provide information concerning the socio-economic characteristics of transit riders.

\section{Discussion of Results}

The data collected is further analyzed to decide a graphical and mathematical relations for the major measures of effectiveness (MO' E). These measurements are necessary to describe the transport and movement phenomena by public transit. The main (MO'E) are those related to the following article effect of Socio economic measures. One of the important social factors related to effect the tendency to use the bus is the sex of riders. Fig. (5), shower that males are in double use of bus as females, due to the familiarity of males to serve the family that the females.

Fig.(6), shows the effect of owning car on the transportation of residents. People getting cars are using buses in $27.5 \%$ only, while those having no car are using bus in $72.5 \%$.

Fig. (7), shows the percent of riders using transit with respect to income level groups, for series (1), for groups having (zero) cars, and series (2) for groups having (1) car only. The mentioned figure shows that, for series (1), the higher percent is (19.17) for riders whose income level is between (0-500) ID, and lower percent is (1.67) for riders whose income level is between (2001-2500) ID. While for series (2) the higher percent is (4.47) and lower percent is (1.67) respectively. Figures (8-14), show the relation between passenger traveling, out bound and inbound, and distances, for all units in the study area. It is clear from figures above that the percent of passenger traveling decreases when the distance increased for all units.

Table (1), illustrates across-classification relationship for percent riders using transit, with respect to car-ownership, and family income in Iraqi Dinar (I.D). The percent of riders using transit is minimized with increasing income level, and when the riders own the car.

Table (2), is the relation between rider age group and sex. Rider age group of (1825) year is the most users of transit.

Table (3), is a relationship between rider sex, and his ability to own car. Males, who have no car are the captive riders to use bus.

\section{Conclusions}

1- A large number of people are using the bus of low cost.

2- A large number of transit riders are of low income level and having no car.

3- There are a great number of traveling passenger in each (Serhildan and Diyary) units, where the loading of riders in the bus is above the capacity of it (seats + stands).

4- Riders of age between (18-25) years are the most users of transit.

5- There are abundant of people who are using transit, their home are far away from the road for a distance more than (200)m.

6- There are no scheduling of transit and highly residential corridors.

7- There are more unimportant bus stop location in all lanes. 


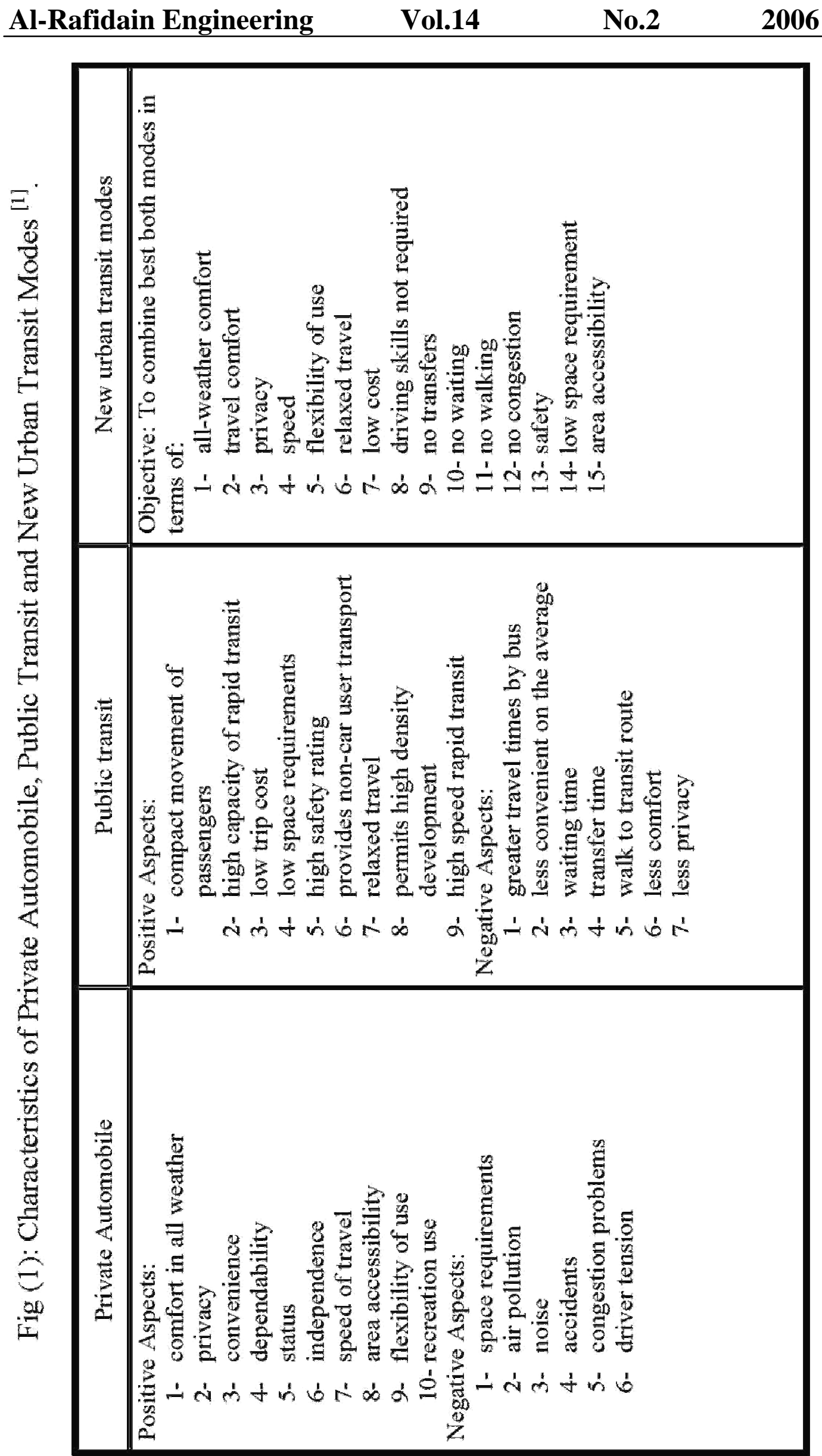


Fig (2): Factors that Influence Determination of Public Transportation Goals in the Community ${ }^{[1]}$.

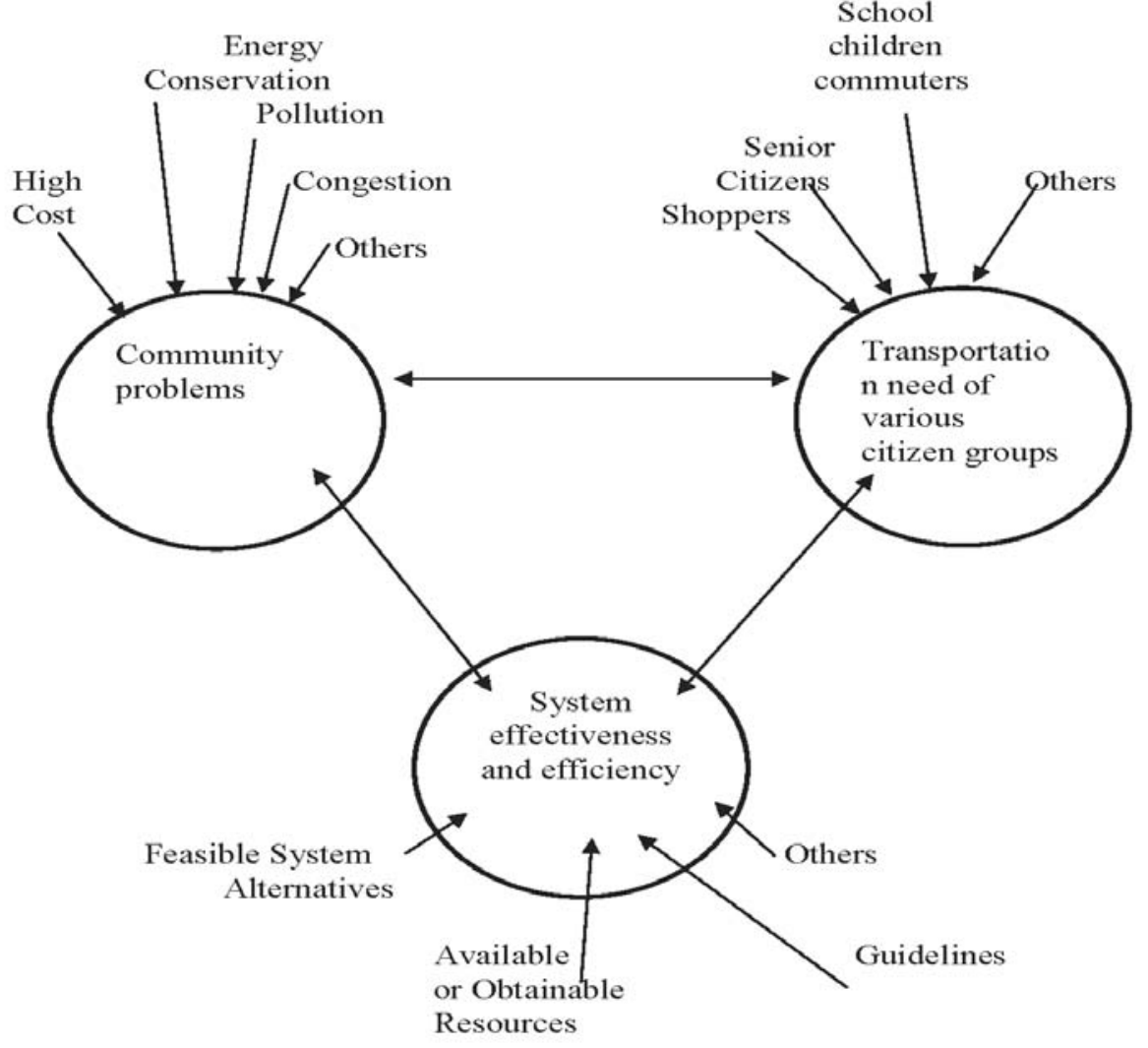

Fig (3) Travel Design Lines in Dohuk City Area

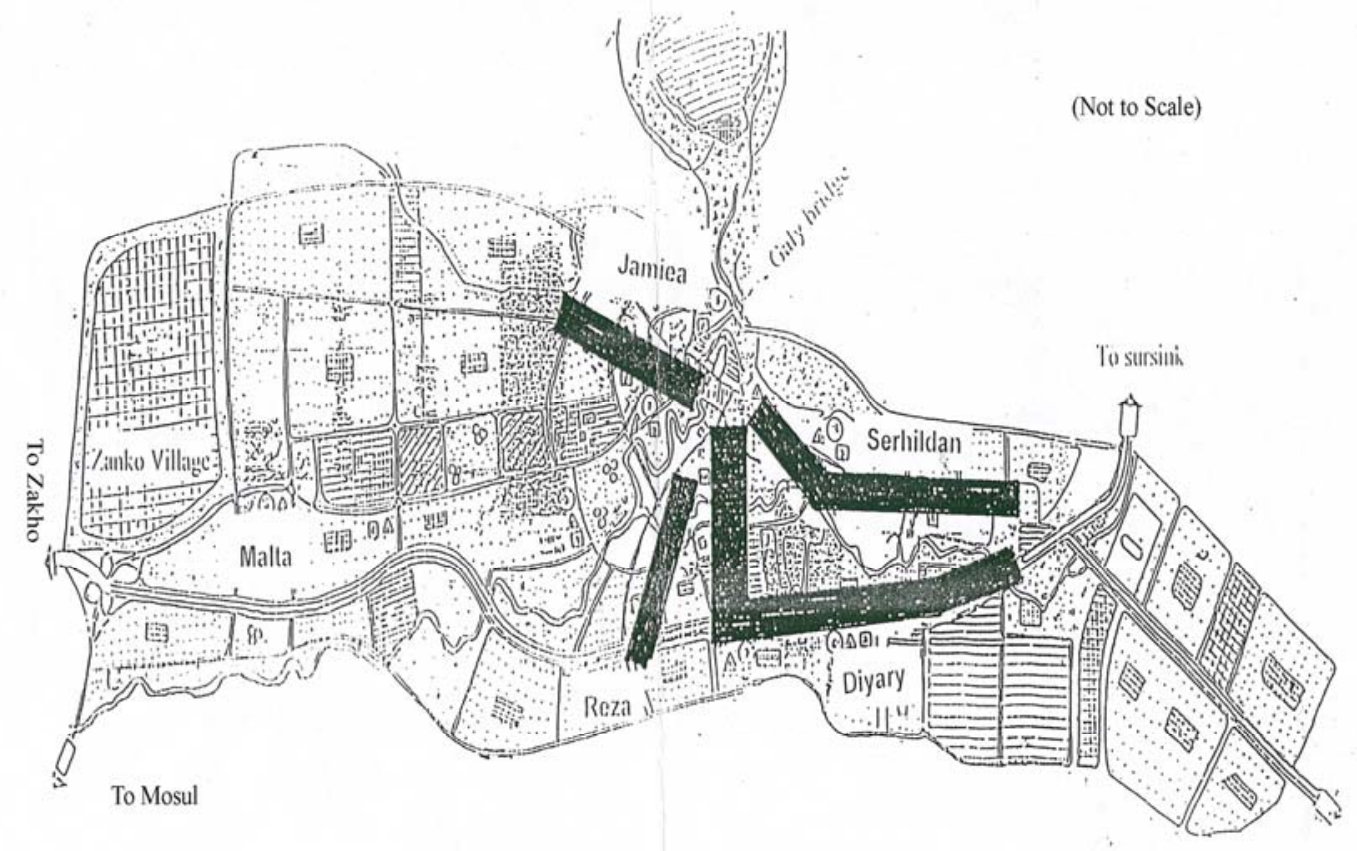


No.2

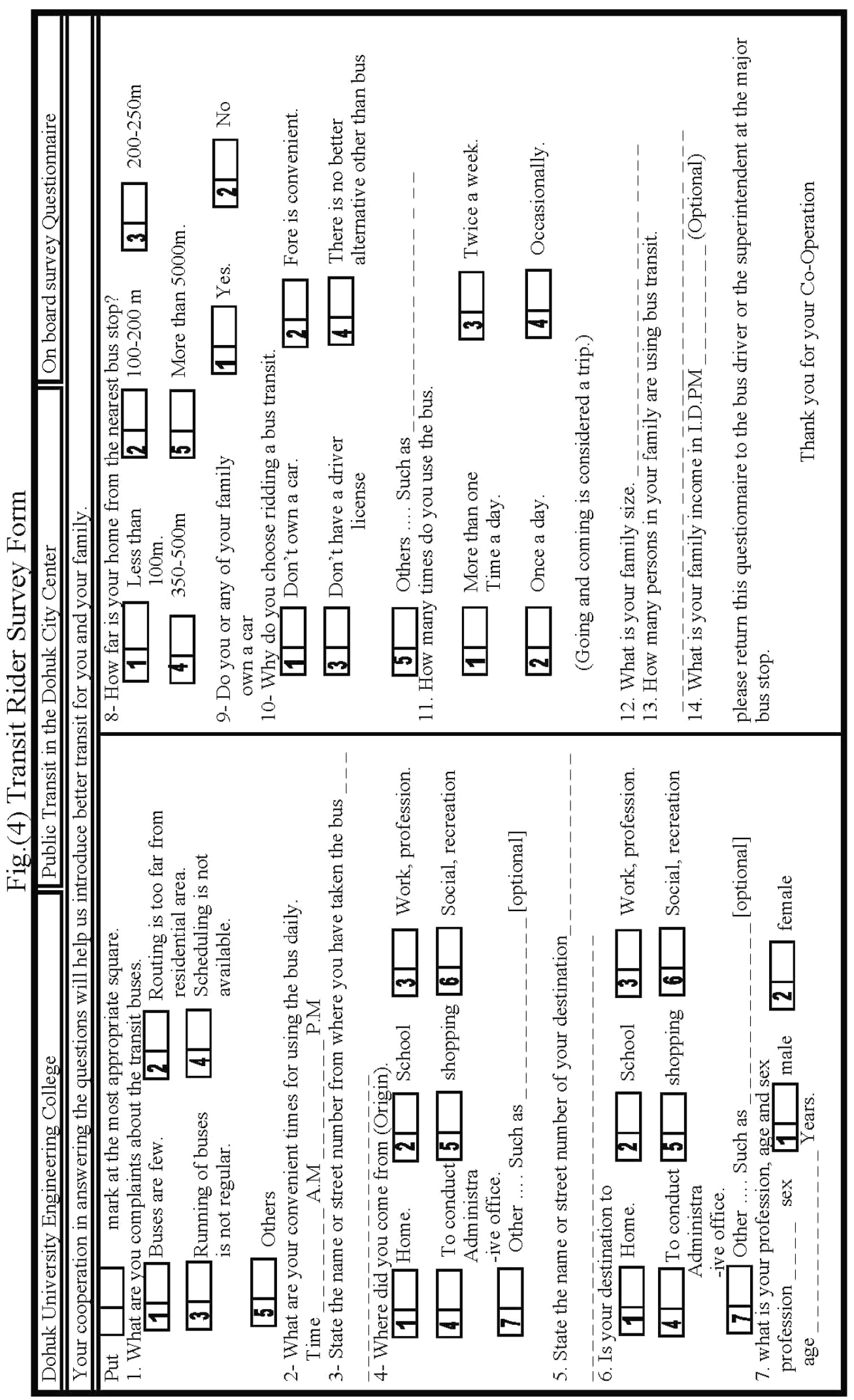


Fig.(5) Transit Riders by Sex in Dohuk (33.33\% Female, 66.66\% Male)

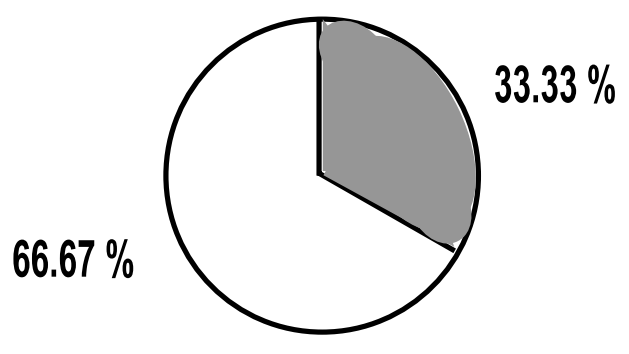

Fig. (6) Percent of Transit Riders Owing an Automobile in Dohuk (27.5\% There is Car Owner in the Family, $72.5 \%$ There is no Car Owner in the Family).
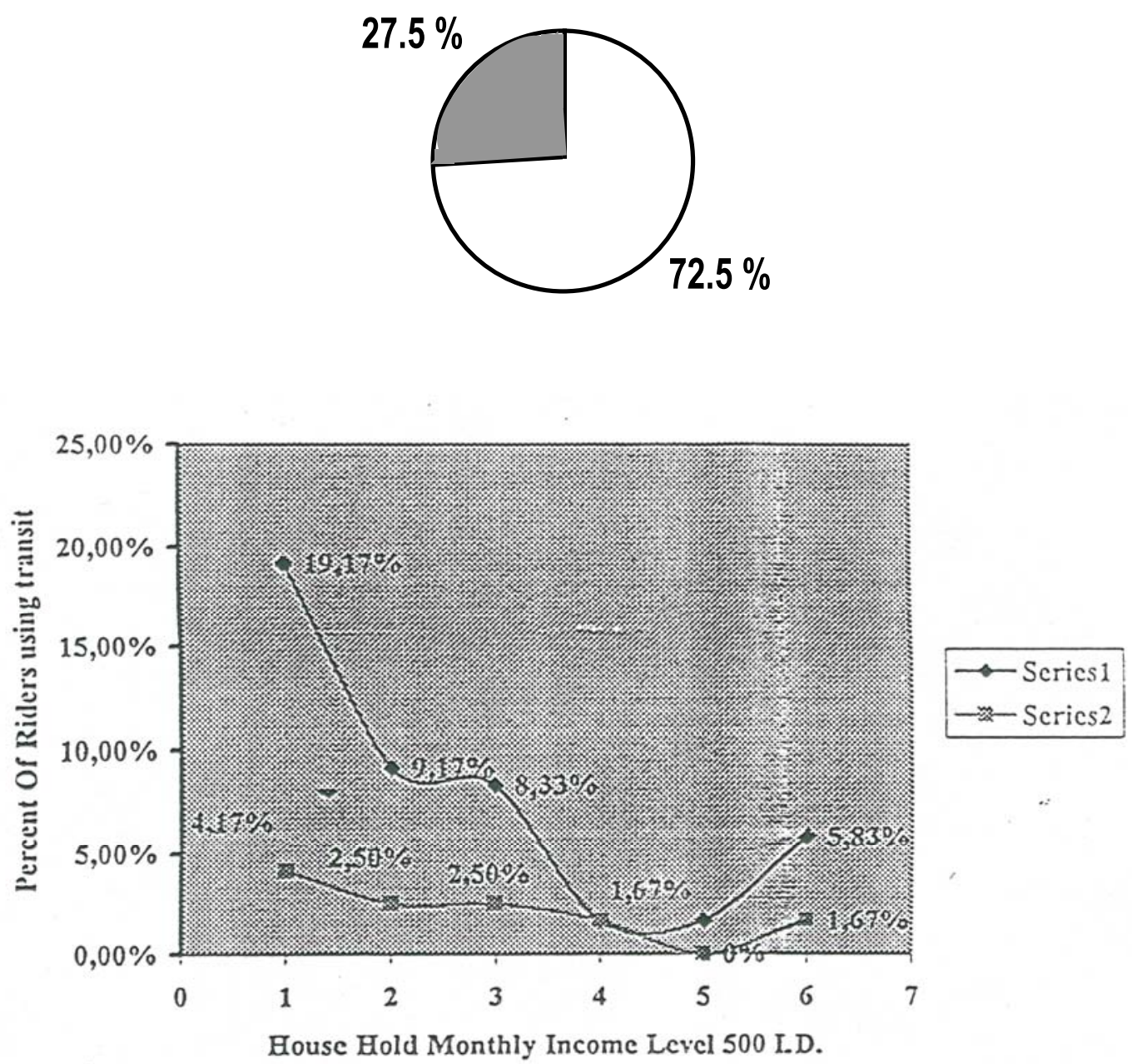
Table (1) In Come Level \& Car Owner Ship.

\begin{tabular}{|c|c|c|c|c|c|c|c|c|}
\hline \multirow{2}{*}{$\begin{array}{c}\text { Car } \\
\text { Owner } \\
\text { Ship }\end{array}$} & \multicolumn{8}{|c|}{ In Come Groups (ID./ MONTH) } \\
\hline & $0-500$ & $\begin{array}{l}501- \\
1000\end{array}$ & $\begin{array}{l}1001- \\
1500\end{array}$ & $\begin{array}{l}1501- \\
2000\end{array}$ & $\begin{array}{l}2001- \\
2500\end{array}$ & $>2500$ & $\begin{array}{l}\text { No } \\
\text { respon } \\
\text { se }\end{array}$ & Total \\
\hline 0 & $\begin{array}{c}23 \\
19.166 \\
\%\end{array}$ & $\begin{array}{c}11 \\
9.167 \\
\%\end{array}$ & $\begin{array}{c}10 \\
8.33 \\
\%\end{array}$ & $\begin{array}{c}2 \\
1.67 \%\end{array}$ & $\begin{array}{c}2 \\
1.67 \%\end{array}$ & $\begin{array}{c}7 \\
5.83 \%\end{array}$ & $\begin{array}{c}32 \\
26.66 \\
\%\end{array}$ & $\begin{array}{c}87 \\
72.5 \%\end{array}$ \\
\hline 1 & $\begin{array}{c}5 \\
4.467\end{array}$ & $\begin{array}{c}3 \\
2.5 \%\end{array}$ & $\begin{array}{c}3 \\
2.5 \%\end{array}$ & $\begin{array}{c}2 \\
1.67 \%\end{array}$ & $\begin{array}{c}0 \\
0 \%\end{array}$ & $\begin{array}{c}2 \\
1.67 \%\end{array}$ & $\begin{array}{c}18 \\
15 \%\end{array}$ & $\begin{array}{c}33 \\
27.5 \%\end{array}$ \\
\hline & $\begin{array}{c}1 \\
19.17 \\
4.17\end{array}$ & $\begin{array}{l}9 . \\
2 .\end{array}$ & $\begin{array}{l}2 \\
\% \\
\%\end{array}$ & $\begin{array}{l}2.98 \\
.33 \% \\
.50 \%\end{array}$ & $\begin{array}{cc}4 & \\
6.67 \% & 1 \\
1.67 \%\end{array}$ & $\begin{array}{l}5 \\
1.67 \% \\
0 \%\end{array}$ & $\begin{array}{c}6 \\
5.83 \% \\
1.67 \%\end{array}$ & \\
\hline
\end{tabular}

Table (2) Relation Between Rider Age Group and Sex.

\begin{tabular}{|c||c||c||c|}
\hline Age Group (Years) & Male & Female & Box Sexes \\
\hline \hline $0-17$ & 3 & 2 & 3 \\
\hline $18-25$ & 47 & 28 & 75 \\
\hline $26-45$ & 26 & 6 & 32 \\
\hline$>45$ & 8 & 0 & 8 \\
\hline \hline Total & 84 & 36 & 120 \\
\hline
\end{tabular}

Table (3) Relation Between Rider Sex, and His Ability to Own Car

\begin{tabular}{|c||c||c||c|}
\hline $\begin{array}{c}\text { Transit Riders By } \\
\text { Sex }\end{array}$ & Own A Car & Don't Own A Car & Total \\
\hline \hline Male & 14 & 66 & 80 \\
\hline Female & 19 & 21 & 40 \\
\hline \hline Total & 33 & 87 & 120 \\
\hline
\end{tabular}


Appendix (1)

Sample Field Sheet for Bus Transit Usage. ${ }^{[10]}$

\begin{tabular}{|c|c|c|c|c|c|c|}
\hline & & Public Tra & isportati & Usage & & \\
\hline Date: & & & Route I & me: & & \\
\hline Route No & & & Directi & n: from & & \\
\hline Bus No.: & & & Weath & & & \\
\hline Seat Capa & & & Standing & Capacity & & \\
\hline & & & & assenge & & \\
\hline Arrival & $\begin{array}{c}\text { Depar- } \\
\text { ture }\end{array}$ & $\begin{array}{l}\text { Location } \\
\text { of stop }\end{array}$ & $\begin{array}{l}\text { Boar- } \\
\text { ding }\end{array}$ & $\begin{array}{c}\text { Aligh- } \\
\text { ting }\end{array}$ & $\begin{array}{l}\text { Occup } \\
\text {-ancy }\end{array}$ & remarks \\
\hline & & & & & & \\
\hline & & & & & & \\
\hline
\end{tabular}

Appendix (2)

Sample Field Sheet for Speed and Delay Study. ${ }^{[10]}$

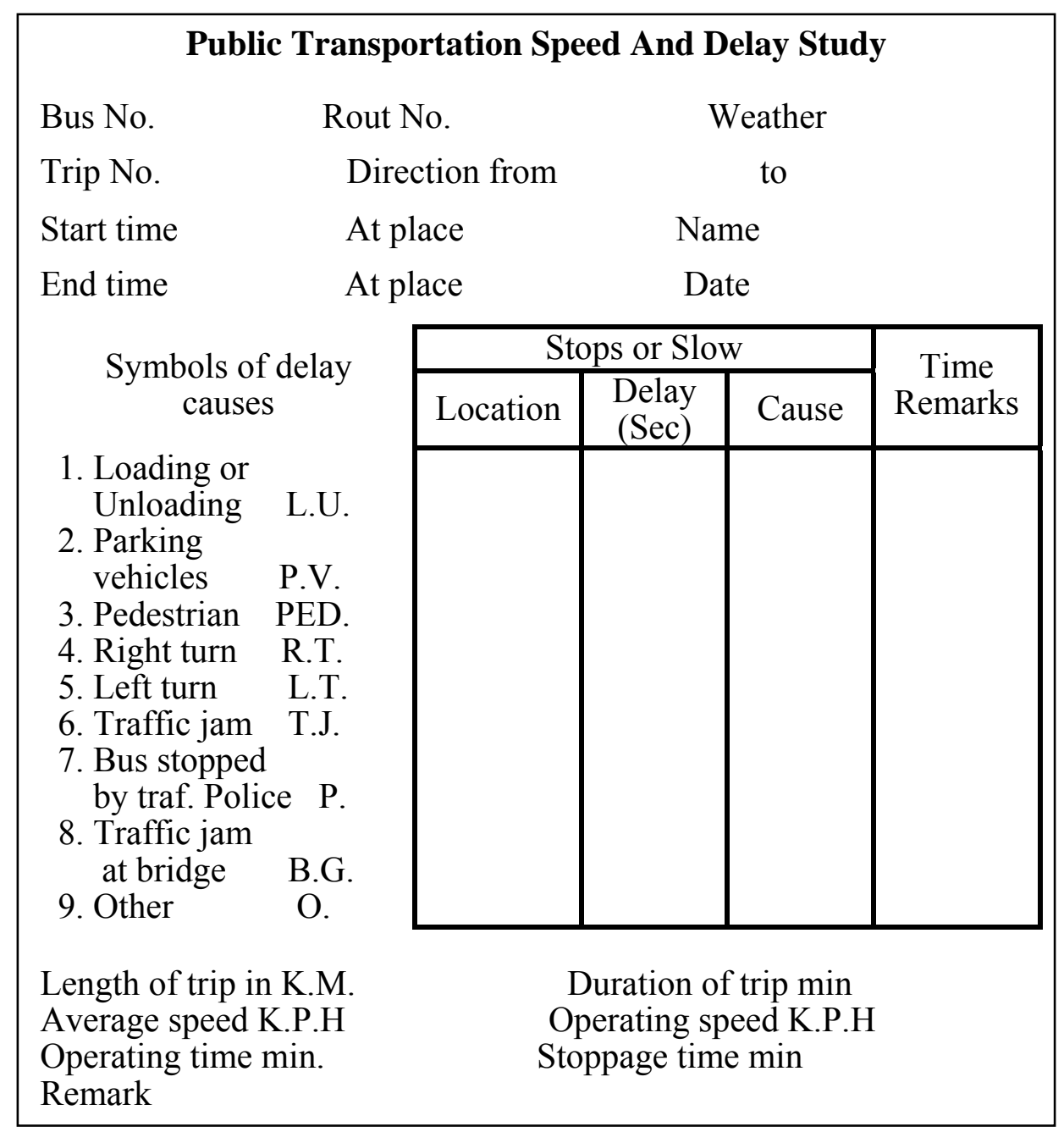




\section{Recommendations}

The study suggested the following recommendations to improve public transit in the study area:

1- Opening a new street in the upper part of the Serhildan unit, because most of the people in this unit there houses are far away from the arterial street more than $(300) \mathrm{m}$.

2- Increasing the trip distance between Reza lane and Shindokha for serving more people in this area.

3- Increasing the number of buses in (Jamiea and Diyary) units.

4- Opening a way or constructing a bridge near the Mazi supermarket to Shindokha unit.

5- Replacing the buses in Jamiea lane and Diyari lane by other new and more comfort buses.

\section{References}

1- Abdul-Basit Abdul-Aziz Mahmood, "Transit planning study in the NorthEastern corridor of Mosul city", M. Sc. thesis, college of Engineering, University of Mosul, 1984.

2- Graven, D.W., et al. "Urban Public Transportation Goal Determination: A Research Approach", TRC. 563, TRB. 1976. PP. (2-5).

3- Levinson, H.S. et Al., "Bus Use of Highways," state of the Art. NCHRP Report 143, HRB, 1973.

4- Hill, F.N., "Public Transportation Operating Standards", Special Report 144, TRB, 1974, P.63.

5- Roos, Danial, "Demand Responsive Transportation Systems", Urban Transportation 1970, P.123.

6- Giman, W.C., and company, "Transit Technical Study", South BendMishawak a Area, 1969.

7- Cooper, E., "Method of Improving Transportation Facilities for Inner-City Dwellers", Howard University, 1970.

8- Deen, Thomas B., and Richard H. , Pratl, "Evaluating Rapid Transit in Public Transportation " $2^{\text {nd }}$ eds, George E Gray and Lester A. Hoel. Prentice Hall, Engle wood Chiffs. NJ. p p (293- 332), 1992.

9- Transportation Research Board (TRB), "Transit Capacity and Quality of Service Manual" , Transit Cooperative Research Program web Document No.6, National Research Council, Washington DC, 1999.

10-Manual of Transit and Traffic Studies, American Transit Association, Washington, D.C., 1972. 